Ju.S. Mazurenko

\title{
Nickel Substituted Effect of on Structural, Mössbauer and Dielectric Properties of Spinel-Type Lithium Ferrites
}

\author{
Ivano-Frankivsk National Medical University, Ivano-Frankivsk, Ukraine, e-mail: yumazurenko@ifnmu.edu.ua
}

\begin{abstract}
$\mathrm{Ni}$-substituted lithium ferrite $\mathrm{Li}_{0.5-\mathrm{x} / 2} \mathrm{Ni}_{\mathrm{x}} \mathrm{Fe}_{2.5-\mathrm{x} / 2} \mathrm{O}_{4}$, where $(\mathrm{x}=0.0,0.2,0.4,0.6,0.8,1.0)$ synthesized through sol-gel auto-combustion method was investigated for its structural, Mossbauer, and dielectric properties. At low doses of substitution, two spinels of the same composition coexist in the structure, one of spatial group $\mathrm{P} 4332$, so-called spinel with superstructure, in which the iron and lithium ions are arranged along the crystallographic direction $\langle 110\rangle$ and the other is a spatial group $\mathrm{Fd} 3 \mathrm{~m}$, random spinel. The presence of both spinels is observed at low content of the doped element $(x=0.2$ and 0.4$)$. In case of increase $\mathrm{Ni}^{2+}$ ions, random component disappears and only the ordered phase remains. The particle sizes of the synthesized product are around $22-45 \mathrm{~nm}$. According to the proposed cationic distribution of Nickel ions are localized in the A-site and lithium ions in the B-site. Iron ions are redistributed over both sites at a ratio of about 1:2. Mössbauer spectra elucidate the nature of the phases and cation distribution. At room temperature showed the presence of three magnetically ordered components and a paramagnetic doublet. It is shown, that the conductive and dielectric properties of the synthesized powders have a frequency dependence characteristic of ferrite materials, the behavior of which is explained based on the hopping mechanism of conductivity and inter-grain polarization. These characteristics are sensitive to the content of Nickel, features of cationic distribution and microstructure.

Keywords: nanoparticles, sol-gel, structural and magnetic phase transitions, Mössbauer spectra, magnetic properties.
\end{abstract}

Received 09 June 2020; Accepted 15 September 2020.

\section{Introduction}

Ferrites are non-conventional and a widely studied ferroelectric material characterized by high magnetic permeability, high saturation magnetization and low losses. These materials are widely used as magnetic fluids, in microwave devices, magnetic recorders, and in the production of radio frequency coils, transformer core transformers, noise filters, and record heads, rod antennas. The possibility of substitution of transition metal ions in different compositions makes ferrites very attractive since properties such as magnetic moment, Neel temperature, degree of inversion, and length of bonding may be modified [1]. Moreover, by substituting the various metal ions in the ferrite, it is possible to obtain the desired structural, vibrational, electrical and magnetic properties.

The structural, magnetic, and electrical properties of ferrites are highly dependent on the cationic distribution, grain size, and synthesis conditions [2,3]. Among the electrical properties of ferrites, the most important characteristics are the dielectric constant, dielectric loss and $\mathrm{AC}$ conductivity, which must be determined in the frequency range required for their application. $\mathrm{Li}_{0.5-x / 2} \mathrm{Ni}_{x} \mathrm{Fe}_{2 / 5-x / 2} \mathrm{O}_{4}$ ferrites have excellent structural, magnetic and electrical properties and can be considered and studied as one of the most important magnetic and catalytic materials due to their low electrical conductivity compared to other magnetic materials [4].

An important issue for $\mathrm{Li}_{0.5-x / 2} \mathrm{Ni}_{x} \mathrm{Fe}_{2 / 5-x / 2} \mathrm{O}_{4}$ is the loss of lithium in prolonged and high-temperature annealing, which takes place in the traditional ceramic synthesis method. Therefore, it is important to develop and improve new efficient and low-temperature synthesis methods, which would ensure a high homogeneity of the synthesized product while maintaining the stoichiometry and relatively small particle size. These requirements are 
met by the sol-gel auto-combustion method [5], in which the required heat is released due to exothermic reactions, a short synthesis time of the minute prevents significant growth of crystallites and mixing of precursors at the molecular level ensures high homogeneity and compliance with stoichiometry.

The magnetic and electrical properties of spinel ferrites strongly depend on both the particle size and the type and quantity of substituted element.

Although some efforts have been made to study the structural, electrical, and magnetic properties of these ferrites, however, no systematic studies have been made on the redistribution of cations by sublattices with increasing nickel concentration. Structural properties obtained from X-ray diffraction studies were supplemented and confirmed by Mossbauer spectroscopy. Also, in this work were carried out detailed studies of the dielectric properties. Magnetic parameters such as the field on the nucleus, isomer shift, and quadrupole moment were obtained from the Mössbauer spectra. We also compared the results of $\mathrm{Ni}^{2+}$ substituted ferrites with results from other researchers. In this paper, we have found that not only the method of preparation, the annealing temperature, but also the concentration of the doping element changes the interaction distances in these ferrites. In addition, in this paper we plan to obtain better dielectric properties at room temperature.

\section{Methodology}

Nickel-substituted lithium-iron spinels of general composition $\mathrm{Li}_{0.5-x / 2} \mathrm{Ni}_{x} \mathrm{Fe}_{2.5-x / 2} \mathrm{O}_{4}$ were synthesized by the sol-gel auto-combustion method.

As initial precursors were used nitrates of iron $\mathrm{Fe}\left(\mathrm{NO}_{3}\right)_{3} \cdot 9 \mathrm{H}_{2} \mathrm{O}, \quad$ lithium $\mathrm{LiNO}_{3}, \quad$ nickel $\mathrm{Ni}\left(\mathrm{NO}_{3}\right)_{2} \cdot 6 \mathrm{H}_{2} \mathrm{O}$, citric acid and aqueous ammonia solution. Calculated according to stoichiometry, starting compounds were dissolved in distilled water and mixed dropwise to obtain a homogeneous solution. To obtain a $\mathrm{pH}$ value of 7 , an aqueous solution of ammonia was added dropwise to the obtained precursor solution. The solutions were dried in an oven to obtain xerogel. The xerogel was placed in an oven and heated to a temperature of about $200-220^{\circ} \mathrm{C}$ after which the mixture flared and because of exothermic reaction was undergoing the synthesis of ferrite. The reaction proceeded quickly (in the order of several minutes) and as a result, as shown by X-ray studies, single-phase spinel was obtained.

$\mathrm{X}$-ray diffraction patterns of the synthesized powder systems were obtained on an X-Ray diffractometer Ultima-IV, p. Rigaku, Japan in $\mathrm{Cu}-\mathrm{K} \alpha$ radiation at temperature $293 \mathrm{~K}$ in Bragg-Brentano geometry in the range of angles $25-90^{\circ}$ in $\mathrm{CuK}-\alpha$ radiation. Analytical processing of experimental diffractograms was carried out by the Rietveld method in the FullProff software. The sizes of coherent scattering regions (CSR) were estimated by the methods of Selyakov-Sherrer and Williamson-Hall.
Absorption spectra of ${ }^{57} \mathrm{Fe}$ were obtained on a Mössbauer spectrometer MS1104EM . As a source of $\gamma$-quanta used ${ }^{57} \mathrm{Co}$ in a chromium matrix with an activity of $100 \mu \mathrm{Ci}$. The decoding of the obtained spectra was carried out in the Univem package calibration with respect to $\alpha-F e$.

The surface morphology of the samples was investigated using a FE-SEM QUANTAFEG 250 scanning electron microscope at an accelerating voltage of $15 \mathrm{kV}$.

The conductivity and dielectric properties of the samples were investigated using an Autolab PGSTAT 12/FRA-2 impedance spectrometer in the frequency range $0.01 \mathrm{~Hz}-100 \mathrm{kHz}$.

\section{Results and discussion}

Structural characteristics were obtained based on XRD analysis. The XRD spectra of the synthesized product are shown in Fig. 1.

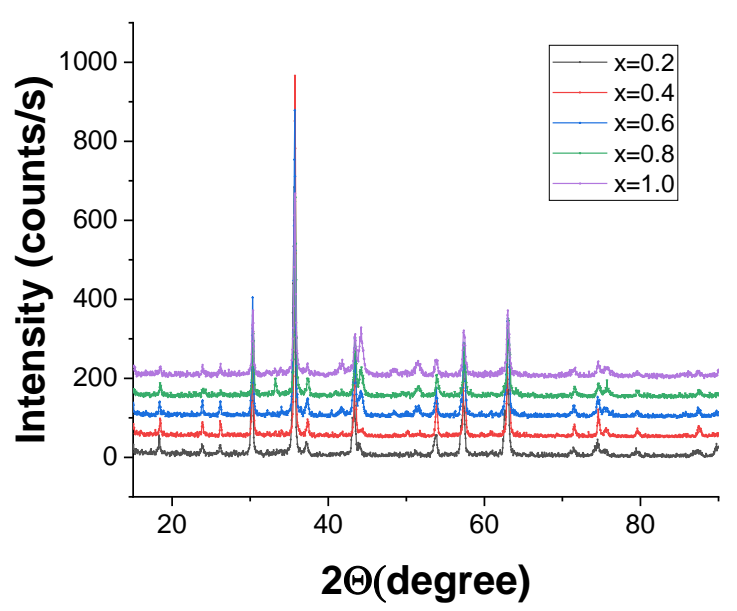

Fig. 1. X-ray diffraction patterns of $\mathrm{Li}_{0.5-0.5 x} \mathrm{Ni}_{x} \mathrm{Fe}_{2.5-0.5 x} \mathrm{O}_{4}$ ferrite synthesized by the sol-gel auto-combustion method.

All samples are crystalline, and two spinels of the same composition can be distinguished: one space group $P_{4} 332$, so-called spinel with superstructure, in which the iron and lithium ions are arranged along the crystallographic direction $\langle 110\rangle$ and the other is a space group $F d 3 m$, disordered spinel. The presence of both spinels is observed at low content of the doped element $(\mathrm{x}=0.2$ and 0.4$)$. In case of increasing $\mathrm{Ni}^{2+}$ disordered component disappears and only the ordered phase remains. In addition to the above, phases in systems also have a low content of metallic nickel. However, the content of metallic nickel does not exceed $5 \%$. Fig. 2 shows the changes in the lattice constant (a), X-ray density (b) and specific surface area (c) at increasing content of nickel ions.

As can be seen from Fig. 2 (a), the value of the lattice constant increases with increasing ion content. $N i^{2+}$. This can be attributed to a larger ionic radius value 
Nickel Substituted Effect of on Structural, Mössbauer and Dielectric Properties...
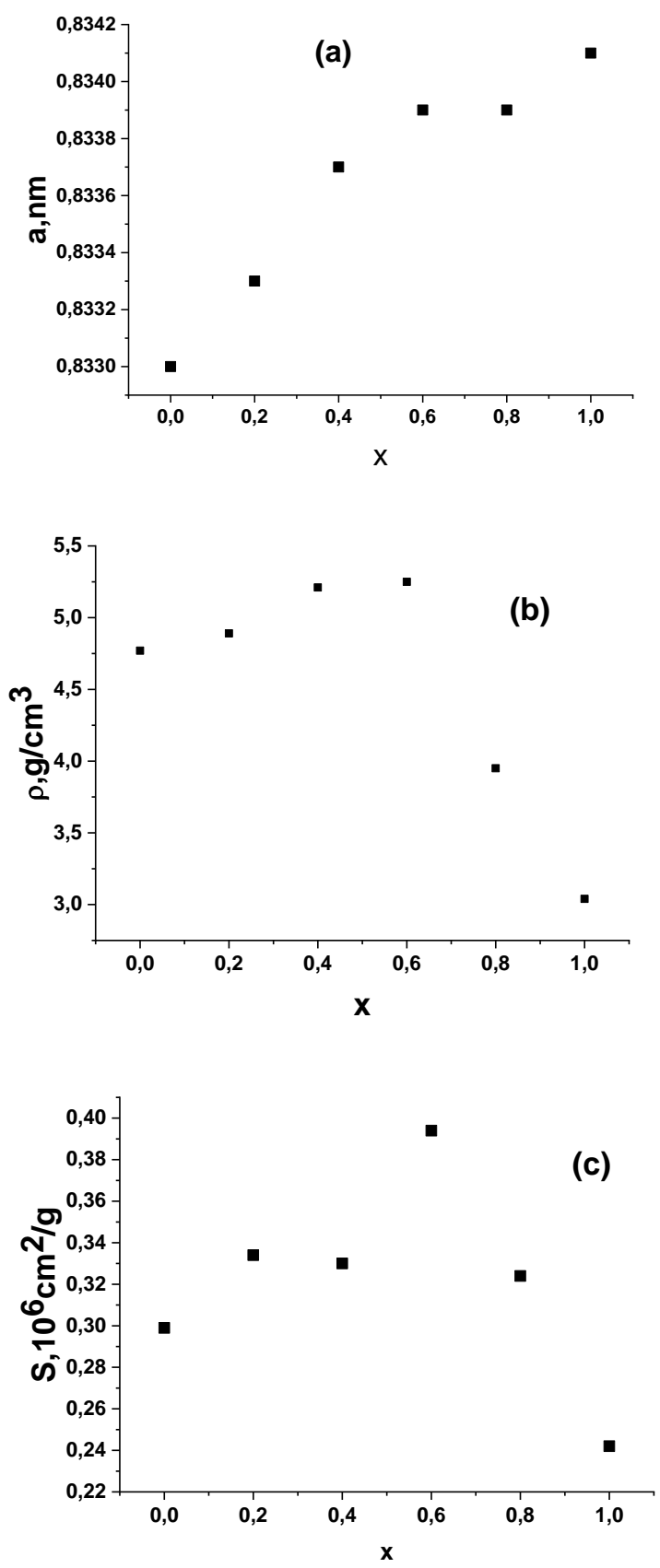

Fig. 2. Change of (a) lattice constant, (б) X-ray density, (в) the specific surface area containing $N i^{2+}$ ions of $\mathrm{Li}_{0.5-0.5 x} \mathrm{Ni}_{x} \mathrm{Fe}_{2.5-0.5 x} \mathrm{O}_{4}$ system obtained by the method of sol-gel auto combustion.

of $\mathrm{Ni}^{2+}(0.69 \mathrm{~A})$, compared to $\mathrm{Fe}^{3+}(0.64 \mathrm{~A})$. Reduction of $\mathrm{x}$-ray density and specific surface area for sample

$\mathrm{x}=1.0$, (Fig. 2 (b, c)), apparently related to the reduction in the size of the octa cavities caused by the absence of lithium ions with a large ionic radius and, consequently, to the reduction of intergranular hyper exchange distances.

The CSR dimensions, which in this case were identical to the crystallites, were determined from the half-width of the lines using the Scherrer formula

$$
D=\frac{k \lambda}{\beta \cos \theta},
$$

where $\lambda$ - wavelength of X-radiation (1.54056 A), $\theta$ diffraction angle of major reflexes, $\beta$ - peak width at half height (FWHM) and k - Scherrer constant taking 0.94 for particles close to spherical cubic symmetry [6]. However, the dependence $\cos \theta$ on $1 / \beta$ (Sherrer's dependence) does not approach the line well (see insert to Fig. 3), indicating the presence of lattice stresses. More precisely, the Williamson Hall equation binds both the crystallite size and the voltage in the lattice caused by the peak widening.
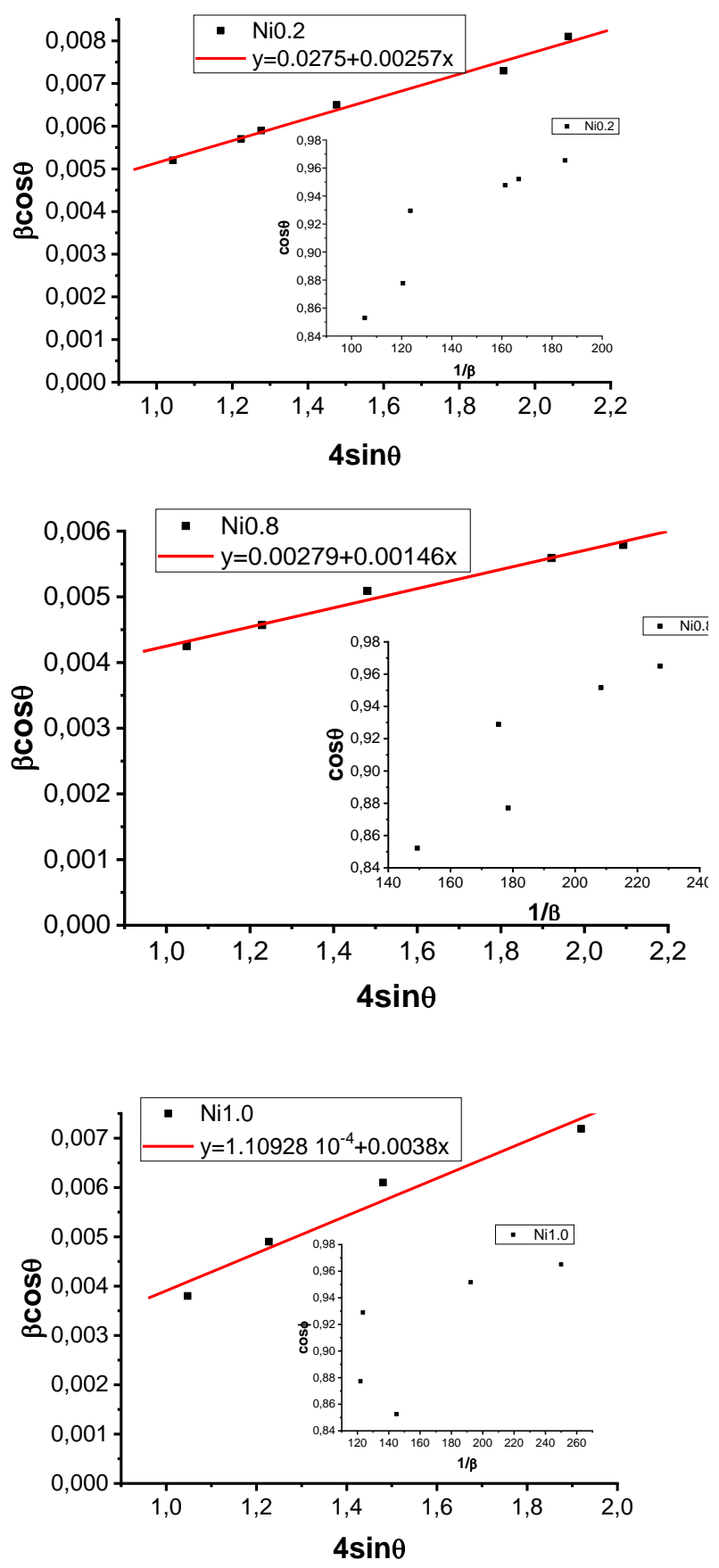

Fig. 3. Williamson-Hall dependencies (left) and Debye-Sherrer (right) for nanoparticles $\mathrm{Li}_{0.5-x / 2} \mathrm{Ni}_{x} \mathrm{Fe}_{2.5-x / 2} \mathrm{O}_{4}$ with different nickel content. 
Table 1

Cationic distribution of elements by lattices and obtained value of a lattice constant of

$\mathrm{Li}_{0.5-x / 2} \mathrm{Ni}_{x} \mathrm{Fe}_{2.5-x / 2} \mathrm{O}_{4}$ system, synthesized by the method of sol-gel auto combustion

\begin{tabular}{|c|c|c|c|c|}
\hline$x$ & A-site & B-site & $\alpha, n m$ & $\Delta \alpha, n m$ \\
\hline 0.0 & $F e_{1.0}$ & $L i_{0.5} F e_{1.41}$ & 0.8330 & \pm 0.0002 \\
\hline 0.2 & $N i_{0.2} F e_{0.78}$ & $L i_{0.4} F e_{1.62}$ & 0.8333 & \pm 0.0002 \\
\hline 0.4 & $N i_{0.4} F e_{0.66}$ & $L i_{0.3} F e_{1.54}$ & 0.8337 & \pm 0.0002 \\
\hline 0.6 & $N i_{0.56} F e_{0.43}$ & $L i_{0.2} F e_{1.47}$ & 0.8339 & \pm 0.0002 \\
\hline 0.8 & $N i_{0.74} F e_{0.21}$ & $L i_{0.1} F e_{1.39}$ & 0.8339 & \pm 0.0002 \\
\hline 1.0 & $N i_{0.93} F e_{0.11}$ & $F e_{1.34}$ & 0.8412 & \pm 0.0002 \\
\hline
\end{tabular}

$$
\beta=\beta_{\text {size }}+\beta_{\text {strain }}=\frac{k \lambda}{D \cos \theta}+4 \varepsilon \tan \theta,
$$

where $\varepsilon$ the micro tension parameter and other characters have the above values. Dependency $\beta \cos \theta$ on $4 \sin \theta$ (W-H dependence, Fig. 3) is a set of points with small scatter indicating the uniformity of the lattice stresses and thus the isotropic nature of the samples. Moreover, the dependence shows a positive slope, reflecting the presence of elastic stresses in the nanoparticles. The size of the crystallites (grains) and the values of the microstresses of the samples, determined according to the intersection and slope of the $\mathrm{W}-\mathrm{H}$ dependencies are shown in the table 3 . As can be seen from the table, there is no clear tendency of influence of the content of the substitute element on the crystallite size. The somewhat larger CSR values for $\mathrm{x}=0.0(42 \mathrm{~nm})$ and $\mathrm{x}=0.4(35 \mathrm{~nm})$ samples are obviously related to the rate of reaction of the combustion itself, which depends on the metal / fuel ratio [7].

Cationic distribution of elements by the sublattices, determined based on experimental x-ray diffraction patterns using a Rietveld refinement method showed that ions $\mathrm{Ni}^{2+}$ are localized in the A-site, ions $\mathrm{Li}^{+}$- in B-site, and ions $\mathrm{Fe}^{3+}$ are distributed over both sublattices in a 1:2 ratio. The distribution of cations by sublattice for all the synthesized samples is shown in table 1 .
Based on the experimentally found values of the lattice constant and the oxygen parameter $(\mathrm{u})$, the values of ion radii for the $\mathrm{A}$ and $\mathrm{B}$-sites, $\mathrm{rA}$ and $\mathrm{rB}$ were calculated by the formulas [13]

$$
\begin{gathered}
r_{A}=C_{A N i} r\left(N i^{2+}\right)+C_{A F e} r\left(F e^{3+}\right), \\
r_{B}=\frac{1}{2}\left[C_{B F e} r\left(F e^{3+}\right)+C_{B L i} r\left(L i^{+}\right)\right],
\end{gathered}
$$

where $r\left(L i^{+}\right), r\left(N i^{2+}\right), r\left(\mathrm{Fe}^{3+}\right)$ ionic radii that make up

$$
\begin{gathered}
r_{A}\left(\mathrm{Ni}^{2+}\right)=0,55 A, r_{B}\left(\mathrm{Li}^{+}\right)=0,72 \mathrm{~A}, \\
r_{A}\left(F e^{3+}\right)=0,49 A \text { i } r_{B}\left(F e^{3+}\right)=0,645 A,[28],
\end{gathered}
$$

and $C_{A N i}, C_{A F e}, C_{B F e}, C_{B L i}$ - the concentrations of the corresponding ions in the A- and B-sites. The calculated values of ion radii for each composition and each sublattice are shown in table 2.

As can be seen from the table, as the nickel content increases, the sizes of the tetrahedral cavities gradually increase, and the octahedral cavities decrease. This is due to the increase in nickel tetra lattice and the decrease in lithium octa lattice with a large ionic radius. Some deviations from monotonicity are obviously due to the presence of a phase of metallic lithium, the content of which increases from $1.7(\mathrm{x}=0.2)$ to $7.23(\mathrm{x}=0.8)$.

Figure 4 shows Mossbauer spectra ${ }^{57} \mathrm{Fe}$ taken at room temperature of systems $\mathrm{Li}_{0.5-\mathrm{x} / 2} \mathrm{Fe}_{2.5-\mathrm{x} / 2} \mathrm{Co}_{\mathrm{x}} \mathrm{O}_{4}$ where $\mathrm{x}=0.0 ; 0.4 ; 0.8$, obtained at a $\mathrm{pH}$ of the reaction medium equal to 7. All spectra obtained are a superposition of three magnetically ordered components and two (for a system with $\mathrm{x}=0.4$ one) paramagnetic doublets.

The effective magnetic fields on ${ }^{57} \mathrm{Fe}$ nuclei with values of $500 \mathrm{kE}$ correspond to the A-site localization of $\mathrm{Fe}^{3+}$ ions, with the fields $490 \mathrm{kE}$ to the tetrahedral environment of iron, and the magnetically ordered component with $\mathrm{H}_{\mathrm{e}}=450 \mathrm{kE}$ to the iron atoms located in the surface layer of crystallite. Table 3 shows the results of the decoding of the experimental Mössbauer spectra of the synthesized samples.

The value of the isomeric shift of the magnetically ordered components indicates the presence of iron in the trivalent state, and the value of quadrupole splitting indicates the spherical symmetry of the field at the nucleus. For effective magnetic fields, both volumetric sublattices tend to decrease. Close values of the obtained

\begin{tabular}{|c|c|c|c|c|c|c|}
\hline Concentration, $x$ & $a_{\text {exp }},(\AA \dot{A})$ & $a_{t h},(\AA ̊)$ & $r_{A},(\AA \dot{A})$ & $r_{B},(\AA \dot{A})$ & $\bar{r},(\AA \dot{A})$ & $u,(\AA ́)$ \\
\hline 0.0 & 8.330 & 8.208 & 0.490 & 0.635 & 0.562 & 0.3721 \\
\hline 0.2 & 8.333 & 8.295 & 0.490 & 0.667 & 0.578 & 0.3760 \\
\hline 0.4 & 8.337 & 8.305 & 0.543 & 0.605 & 0.574 & 0.3778 \\
\hline 0.6 & 8.339 & 8.316 & 0.519 & 0.527 & 0.523 & 0.3759 \\
\hline 0.8 & 8.339 & 8.327 & 0.510 & 0.484 & 0.497 & 0.3759 \\
\hline 1.0 & 8.412 & 8.319 & 0.565 & 0.432 & 0.524 & 0.3715 \\
\hline
\end{tabular}
results indicate validity of this assessment method.

Table 2

Mean ionic radii at $\mathrm{A}$ and $\mathrm{B}$ sites $\left(\left\langle r_{A}\right\rangle\right.$ and $\left\langle r_{B}\right\rangle$, respectively), oxygen positional parameter $(u)$ and sites occupancy in $\mathrm{NiFe}_{2} \mathrm{O}_{4}$ nanoparticles synthesizes at different $\mathrm{pH}$ values of 9 and 11 
Nickel Substituted Effect of on Structural, Mössbauer and Dielectric Properties...

Table 3

Mössbauer data analysis of $\mathrm{Li}_{0.5-x / 2} \mathrm{Ni}_{x} \mathrm{Fe}_{2.5-x / 2} \mathrm{O}_{4}$ system, measured at $293 \mathrm{~K}$

\begin{tabular}{|c|c|c|c|c|c|c|}
\hline Composition & Localization $F e^{3+}$ & $\begin{array}{c}\text { Is } \\
\mathrm{mm} / \mathrm{s}\end{array}$ & $\begin{array}{l}\text { Qs } \\
\mathrm{m} / \mathrm{s}\end{array}$ & $\begin{array}{l}\mathrm{He} \\
\mathrm{kE}\end{array}$ & $\begin{array}{c}\mathrm{S} \\
\mathrm{mm} / \mathrm{s}\end{array}$ & $\begin{array}{c}\mathrm{G} \\
\mathrm{mm} / \mathrm{s}\end{array}$ \\
\hline \multirow{4}{*}{$L i_{0.5} F e_{2.5} O_{4}$} & Sextet B & 0,3557 & 0,0080 & 507,76 & 40,29 & 0,3500 \\
\hline & Sextet A & 0,2606 & $-0,0169$ & 496,87 & 51,04 & 0,45250 \\
\hline & Sextet surf & 0.3356 & -0.504 & 455.53 & 8.67 & 0.7760 \\
\hline & doublet & - & - & - & - & - \\
\hline \multirow{4}{*}{$L i_{0.4} F e_{2.4} N i_{0.2} O_{4}$} & Sextet B & 0.3505 & 0.0702 & 500.32 & 66.45 & 0.4698 \\
\hline & Sextet A & 0.4369 & -0.5869 & 496.40 & 11.77 & 0.3543 \\
\hline & Sextet surf & 0.5853 & 0.0520 & 454.08 & 17.74 & 0.5867 \\
\hline & doublet & 0.4613 & 0.6448 & - & 4.05 & 0.5730 \\
\hline \multirow{4}{*}{$L i_{0.3} F e_{2.3} N i_{0.4} O_{4}$} & Sextet B & 0.3286 & 0.0076 & 507.27 & 60.81 & 0.4648 \\
\hline & Sextet A & 0.2776 & -0.0226 & 492.71 & 38.12 & 0.4648 \\
\hline & Sextet surf & - & - & - & - & - \\
\hline & doublet & 0.3801 & 2.5857 & - & 1.06 & 0.206 \\
\hline \multirow{4}{*}{$L i_{0.2} F e_{2.2} N i_{0.6} O_{4}$} & Sextet B & 0.4352 & -0.0191 & 503.91 & 69.87 & 0.4517 \\
\hline & Sextet A & 0.2670 & -0.0784 & 498.45 & 19.40 & 0.5136 \\
\hline & Sextet surf & 0.5585 & -0.189 & 457.12 & 7.50 & 0.6640 \\
\hline & doublet & 0.2049 & 1.087 & - & 3.22 & 0.9304 \\
\hline \multirow{4}{*}{$L i_{0.1} F e_{2.1} N i_{0.8} O_{4}$} & Sextet B & 0.3530 & -0.0501 & 505.51 & 73.45 & 0.5923 \\
\hline & Sextet A & 0.1811 & -0.0124 & 492.35 & 19.85 & 0.4266 \\
\hline & Sextet surf & 0.6237 & 0.1390 & 449.05 & 4.02 & 0.8481 \\
\hline & doublet & 0.3334 & 0.8521 & - & 2.68 & 0.4796 \\
\hline \multirow{4}{*}{$F e_{2.0} N i_{1.0} O_{4}$} & Sextet B & 0.3295 & 0.0299 & 499.4 & 84.99 & 0.5292 \\
\hline & Sextet A & 0.5490 & 0.0098 & 495.53 & 5.64 & 0.3140 \\
\hline & Sextet surf & 0.8796 & 0.08501 & 445.67 & 1.49 & 0.4062 \\
\hline & doublet & 0.2727 & 1.0464 & - & 7.88 & 0.6395 \\
\hline
\end{tabular}
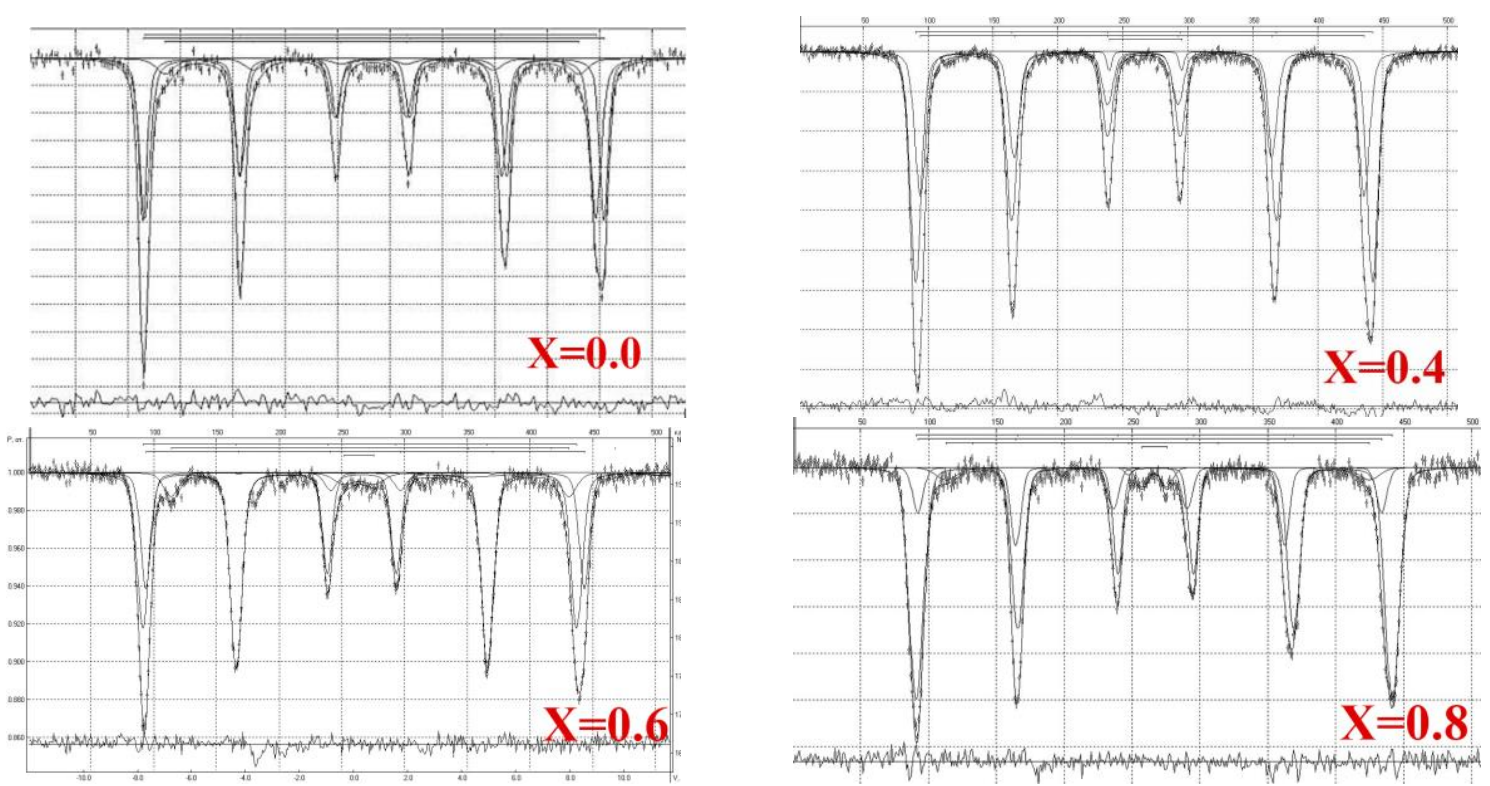

Fig. 4. Mossbauer spectra ${ }^{57} \mathrm{Fe}$ taken at temperature $293 \mathrm{~K}$ of systems $\mathrm{Li}_{0.5-\mathrm{x} / 2} \mathrm{Fe}_{2.5-\mathrm{x} / 2} \mathrm{Co}_{\mathrm{x}} \mathrm{O}_{4}$ where $\mathrm{x}=0.0 ; 0.4 ; 0.6 ; 0.8$, obtained at a $\mathrm{pH}$ of the reaction medium equal to 7 .

Fig. 5 shows the change in the magnetic fields of the A- and B- coordinated ${ }^{57} \mathrm{Fe}$. Obviously, the gradual decrease in the effective magnetic field in the A- lattice is due to the replacement of Nickel ions in place of $\mathrm{Fe}^{3+}$ ions, because nickel has a smaller value of the effective magnetic moment compared to iron. The decrease in the magnetic field in the $B$ - lattice is due to the corresponding decrease in iron ions in the system during substitution. 


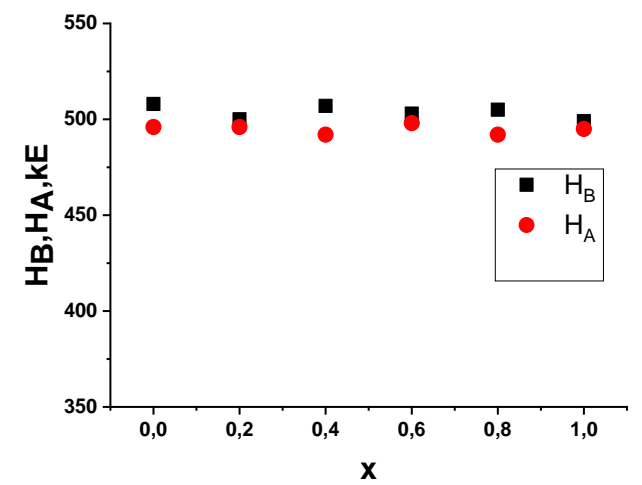

Fig. 5. Changing the effective magnetic fields on ${ }^{57} \mathrm{Fe}$ nuclei depending on the content of Nickel ions.

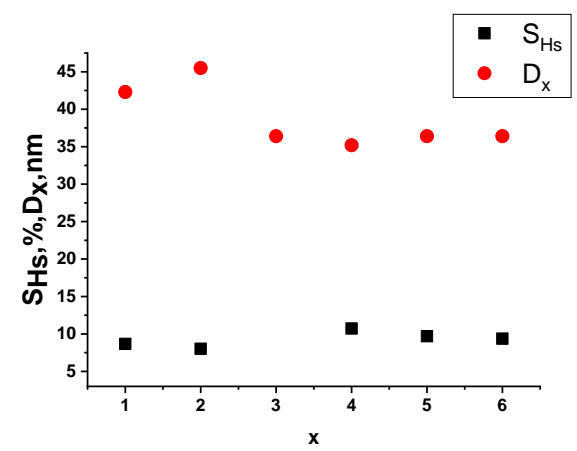

Fig. 6. Dependence of the area under the third magnetically ordered component $\left(\mathrm{S}_{\mathrm{Hs}}\right)$ and the average particle size, determined by X-Ray data $\left(\mathrm{D}_{\mathrm{X}}\right)$ from the content of Nickel ions.

Table 4

Particle sizes obtained from the X-Ray data and from Mössbauer data analysis of $\mathrm{Li}_{0.5-x / 2} \mathrm{Ni}_{x} \mathrm{Fe}_{2.5-x / 2} \mathrm{O}_{4}$

\begin{tabular}{|c|c|c|c|}
\hline \multirow[b]{2}{*}{ Composition } & \multicolumn{2}{|c|}{ X-Ray data } & \multirow[b]{2}{*}{$\begin{array}{c}\text { Crystalline } \\
\text { size, } D_{x}, \\
n m, \\
\text { results } \\
\text { obtained } \\
\text { from } \\
\text { Mössbauer } \\
\text { data } \\
\text { analysis } \\
\end{array}$} \\
\hline & $\begin{array}{c}\text { CSR } \\
\text { size } \\
\mathrm{D}_{\mathrm{x}}, \mathrm{nm} \\
\text { Debye- } \\
\text { Scherrer } \\
\text { method }\end{array}$ & $\begin{array}{c}\text { CSR size } \\
\mathrm{D}_{\mathrm{x}}, \mathrm{nm} \\
\text { Williamson } \\
\text { Hall } \\
\text { method }\end{array}$ & \\
\hline $\mathrm{Li}_{0.5} \mathrm{Fe}_{2.5} \mathrm{O}_{4}$ & 42.1 & 41.6 & 43 \\
\hline $\mathrm{Li}_{0.4} \mathrm{Fe}_{2.4} \mathrm{Ni}_{0.2} \mathrm{O}_{4}$ & 23.0 & 22.9 & 25 \\
\hline$L i_{0.3} \mathrm{Fe}_{2.3} \mathrm{Ni}_{0.4} \mathrm{O}_{4}$ & 34.9 & 34.0 & 37 \\
\hline$L i_{0.2} F e_{2.2} N i_{0.6} O_{4}$ & 30.0 & 29.7 & 33 \\
\hline $\mathrm{Li}_{0.1} \mathrm{Fe}_{2.1} \mathrm{Ni}_{0.8} \mathrm{O}_{4}$ & 29.0 & 28.7 & 33 \\
\hline $\mathrm{Fe}_{2.0} \mathrm{Ni}_{1.0} \mathrm{O}_{4}$ & 26.7 & 26.4 & 30 \\
\hline
\end{tabular}

The presence in the Mössbauer spectra of the third magnetically ordered component $H_{\text {surf }}$, which we attribute to the iron atoms in the surface layer of the crystallite, allows us to estimate the particle size. Figure 6 shows the dependence of the area under the third magnetically ordered component ( $S_{H s}$ ) and the average particle size determined by $\mathrm{x}$-ray data $\left(D_{x}\right)$ on the content of Nickel ions.

As can be seen from the figure, there is a clear inverse relationship: a larger area corresponds to a
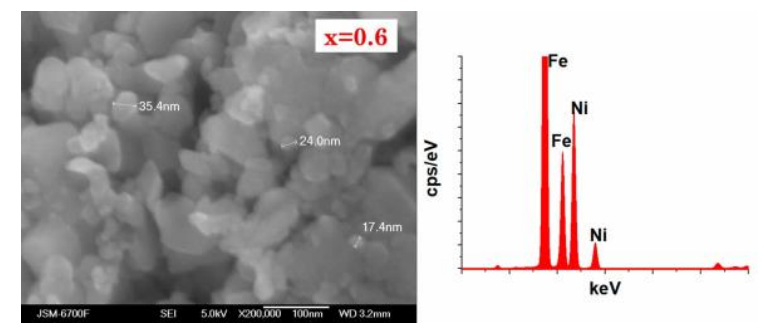

Fig. 7. SEM image of the agglomerated particle of the synthesized material of $\mathrm{Li}_{0.2} \mathrm{Fe}_{2.2} \mathrm{Ni}_{0.6} \mathrm{O}_{4}$ composition.
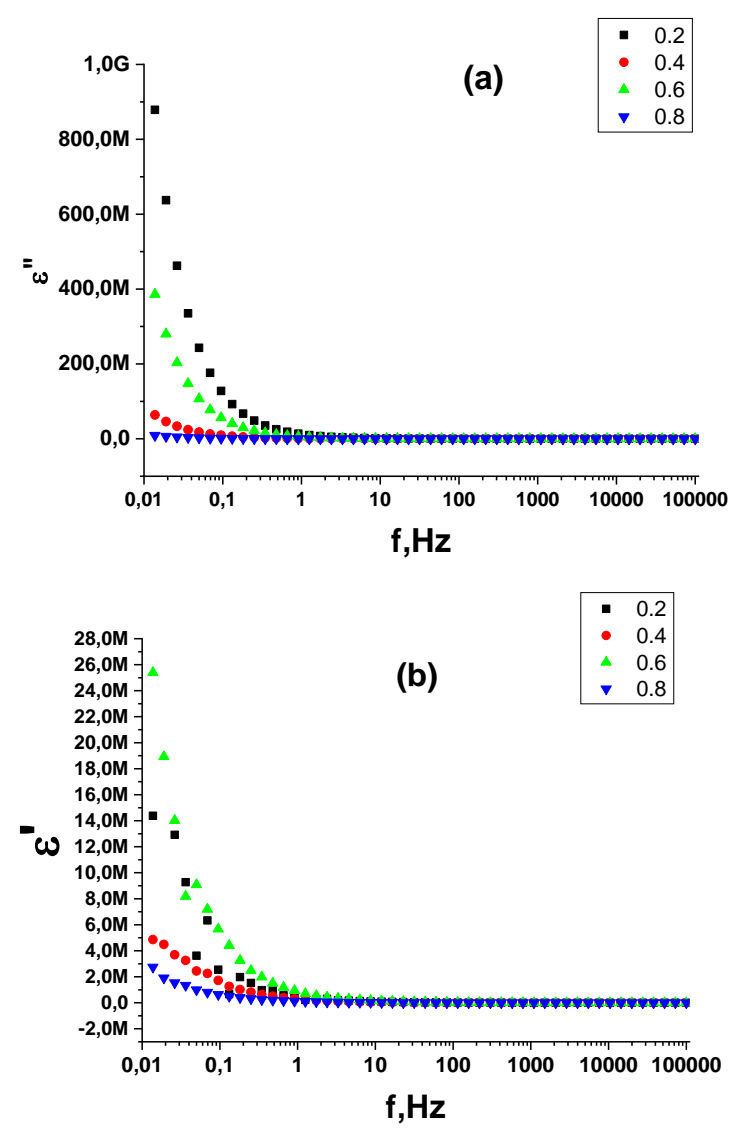

Fig. 8. Frequency dependence of real (a) and imaginary (b) parts of dielectric constant.

smaller particle size. Reduction of effective magnetic fields on ${ }^{57} \mathrm{Fe}$ nuclei associated with different amounts of indirect exchange bonds for internal and surface iron ions, which are deprived of a significant part of such connections [8]. Particle size it is possible to estimate, taking into account value of areas under the subspectra.

At the same time the assumption of a spherical shape of particles was taken into account. Table 4, along with data on the size of the crystallites obtained from x-ray data, shows the calculated data from Mössbauer data analysis. The calculations were performed on the assumption that the particles have a spherical shape. To 
confirm this assumption, studies were performed using a scanning electron microscope. Fig. 7 shows an image of agglomerated particles, from which we can conclude the possibility of such an assumption.

Important for the use of ferrites in high-frequency devices and means of communication is their low conductivity and relatively high values of dielectric constant.

The dielectric properties of ferrites depend on a number of factors, including the method of preparation, sintering time, sintering temperature, particle size, type and amount of replacement element, etc.. Dielectric parameters at room temperature in the frequency range $0.01 \mathrm{~Hz}-105 \mathrm{~Hz}$ were calculated from the impedance spectra based on the equations [9]. Frequency dependence of the real part of the dielectric constant $\left(\varepsilon^{\prime}\right)$ and the imaginary part of the dielectric constant $\left(\varepsilon^{\prime \prime}\right)$ at room temperature are shown in Fig. 8 (a) and (b).

The figures show that the values of $\varepsilon^{\prime}$ and $\varepsilon^{\prime \prime}$ gradually decrease with increasing frequency. Above a certain value of frequency, dielectric parameters do not change with frequency, ie become independent of frequency. This fact shows the normal dependence of ferromagnetic materials.

The change in the dielectric constant with frequency can be explained based on the phenomenon of spatial polarization of charges [10]. According to it, the dielectric material has highly conductive grains separated by highly resistant grain boundaries. In the applied

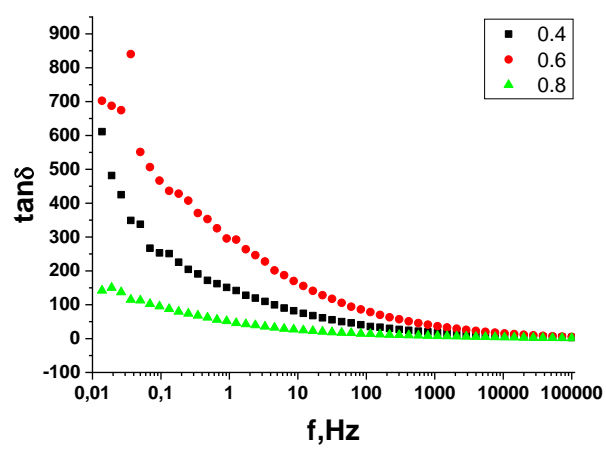

Fig. 9. Changing loss tangent $\tan \delta$ with frequency for systems $\mathrm{Li}_{0.5-x / 2} \mathrm{Ni}_{x} \mathrm{Fe}_{2 / 5-x / 2} \mathrm{O}_{4}$

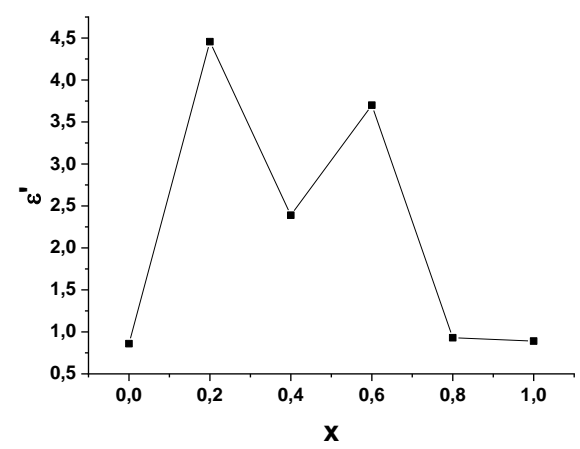

Fig. 10. Dependence of the real part of the dielectric constant at a frequency of $1000 \mathrm{~Hz}$ on the content of Nickel ions.

electric field, the spatial charge accumulates at the grain boundaries and the voltage drop occurs mainly at the grain boundaries [11]. Kups suggested that grain boundaries do its effect mainly at low frequencies [11]. With increasing frequency of electron exchange between $\mathrm{Fe}^{2+}$ and $\mathrm{Fe}^{3+}$ does not have time to be realized during the change of direction of the external field, in other words, the jump frequency has a certain limit and with increasing frequency relative to the limit, the value of the dielectric constant becomes constant.

The change of dielectric parameters with frequency has a mechanism similar to the conduction process [12]. In the electronic exchange between ions $\mathrm{Fe}^{2+}$ and $\mathrm{Fe}^{3+}$ there is a shift of the electron cloud in the direction of the applied field, which, in fact, determines the polarization. The polarization decreases with increasing frequency and then reaches a constant value. This is because the frequency of $\mathrm{Fe}^{2+} \leftrightarrow \mathrm{Fe}^{3+}$ electron exchange lags behind the frequency of change of the external field. The high value of the dielectric constant at low frequencies is a consequence of the predominant amount in the sample of $\mathrm{Fe}^{2+}$-type ions, oxygen vacancies, defects in grain boundaries, etc.. [12] Whereas the decrease in the dielectric constant with frequency is natural, i.e. any samples show that the polarizability decreases with increasing frequency. Thus, the mechanism of electronic conductivity can be explained based on the jump of an electron between the same elements that is in different valence states $\left(\mathrm{Fe}^{3+} / \mathrm{Fe}^{2+}\right.$ and $\left.\mathrm{Ni}^{2+} / \mathrm{Ni}^{+}\right)$.

The change in the tangent of material losses with frequency is shown in Fig. 9.

The figure shows that $\tan \delta$ decreases with increasing frequency and its value is very small at high frequencies. Thus, this material is suitable for highfrequency microwave applications. Change of dielectric constant Li-Ni nanoferrites with $\mathrm{Ni}$ composition shown in Fig. 10. The figure shows that at room temperature the dielectric constant increases with increasing $\mathrm{Ni}$ concentration from 0.0 to 0.2 . Obviously, as the $\mathrm{Ni}$ content increases, the $\mathrm{Fe}^{3+}$ ion content increases in the Bposition, because, according to the cationic distribution, Nickel ions occupy the A-sublattice, displacing iron ions in the B-sublattice, thus reducing the jump of electrons, which in turn causes the accumulation of electrons at the grain boundaries. Thus, the dielectric constant increases. Some researchers [13] observed the same anomalous dependence.

The frequency dependence of the AC conductivity of the obtained ferrites is shown in Fig.11. The figure shows that the AC conductivity of the synthesized samples reveals the frequency dispersion.

At low frequencies, the conductivity is mostly constant. However, after a certain frequency, it increases rapidly. This behavior can be explained based on Kups' theory [11], which suggests that the ferrite material can be considered as a two-layer capacitor. According to the two-layer model of ferrite according to Kups, the first layer is a conductive layer consisting of conductive grains of ferrite, separated by a second layer - weakly conductive grain boundaries. Kups suggested that grain boundaries dominate at lower frequencies and result in low conductivity. As the frequency increases, the conductive grain boundaries dominate, resulting in an 


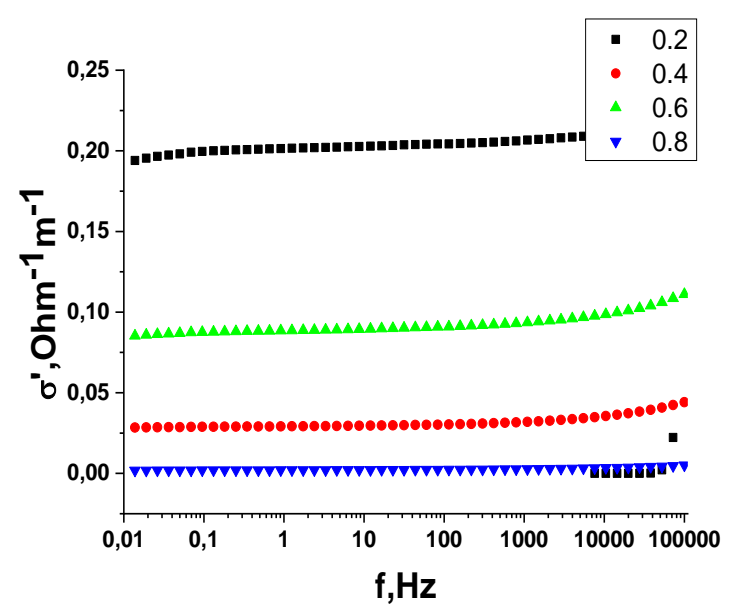

a)

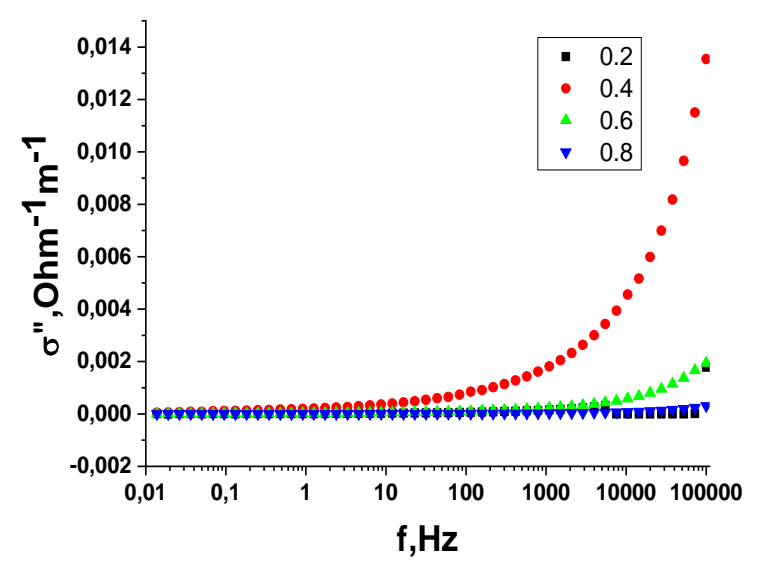

b)

Fig. 11. Dependence of real (a) and imaginary (b) parts of conductivity on frequency.

increase in the electron jump between $\mathrm{Fe}^{2+}$ and $\mathrm{Fe}^{3+}$ ions, and the conductivity increases.

\section{Conclusions}

Substitution of $\mathrm{Ni}^{2+}$ ions in the basic lithium ferrite affects its structural and dielectric properties. The size of the crystallites of the synthesized samples is in the range of $25-45 \mathrm{~nm}$, which allows them to be attributed to the nanocrystalline structure. Increasing the concentration increases the lattice parameter and the jump length between the A- and B positions. Mössbauer spectra showed three magnetically ordered components and a paramagnetic doublet, the parameters of which change when the content of Nickel ions changes.

The dielectric constant and the dielectric loss tangent decrease with increasing frequency, which indicates the semiconductor nature of ferrites. The conductivity of the synthesized samples increases with increasing frequency. Thus, the structural and morphological, Mössbauer parameters and conductive and dielectric properties are sensitive to the content of Nickel ions, which makes it possible to purposefully modify the material in accordance with technological needs.

\section{Acknowledgements}

Author acknowledge faculty of Physical Engineering, Igor Sikorsky Kyiv Polytechnic Institute National Technical University of Ukraine for X-ray measurements, Faculty of Physics and Technology, Vasyl Stefanyk Precarpathian National University, Ukraine for Mössbauer measurements.

Mazurenko Ju. S. - Candidate of Physical and Mathematical Sciences, Assistant Professor at the Department of Medical Informatics, Medical and Biological Physics.

[1] L.S. Kaykan, A.K. Sijo, Appl Nanosci (2020) (https://doi.org/10.1007/s13204-020-01413-y).

[2] L. Sun, J Magn Magn Mater. 449, 545 (2017) (https://doi.org/10.1016/j.jmmm.2017.10.104).

[3] M.A. Ahmed, J Magn Magn Mater. 324, 4 (2012) (https://doi.org/10.1016/j.jmmm.2011.07.010).

[4] R. Masrour, J Magn Magn Mater. 363, 1 (2014) (https://doi.org/10.1016/j.jmmm.2014.03.043).

[5] A. Gholizadeh, J Magn Magn Mater. 422, 328 (2017) (https://doi.org/10.1016/j.jmmm.2016.09.029).

[6] L. Sun, R. Zhang, Z, J. Magn. Magn. Mater. 421, 65 (2017) (https://doi.org/10.1016/j.jmmm.2016.08.003).

[7] R. Kumar, M. Kar, Ceram. Int., 42, 6640 (2016) (https://doi.org/10.1016/j.ceramint.2016.01.007).

[8] L.S. Kaykan, I.P. Yaremiy, J. Nano- Electron. Phys. 11(5), 05041(7pp) (https://doi.org/10.21272/jnep.11(5).05041).

[9] B.K. Ostafiychuk, L.S. Kaykan, Nanoscale Res Lett 12, 237 (2017) (https://doi.org/10.1186/s11671-017-19761).

[10] L.S. Kaykan, J.S. Mazurenko, IEEE 39th International Conference on Electronics and Nanotechnology (ELNANO), Kyiv, Ukraine, pp. 97-101, (2019) (https://doi.org/10.1109/ELNANO.2019.8783221).

[11] M.A. Dar, D. Varshney, J. Magn. Magn. Mater. 436, 101 (https://doi.org/10.1016/j.jmmm.2017.04.046).

[12] A.K. Nikumbh, R.A. Pawar, J. (https://doi.org/10.1016/j.jmmm.2013.11.052).

[13] Md.D. Rahaman, T. Nusrat, J. (https://doi.org/10.1016/j.jmmm.2017.11.066).

$\begin{array}{lllll}\text { Magn. } & \text { Magn. } & \text { Mater. } & 355, & 201 \\ \text { Magn. } & \text { Magn. } & \text { Mater. } & 451, & 391\end{array}$


Ю.С. Мазуренко

\section{Вплив заміщення нікелю на структурні, мессбауерівські та діелектричні властивості літісвих феритів шпінельного типу}

Івано-Франківський Національний медичний університет, Івано-Франківськ, Украйна, е-таil: уитаzигепко@ifnти.еdи.иа

В даній роботі показано вплив заміщення іонів $\mathrm{Ni}^{2+}$ в літієвому фериті-шпінелі $\mathrm{Li}_{0.5-x / 2} \mathrm{Ni}_{x} \mathrm{Fe}_{2.5-x / 2} \mathrm{O}_{4}$ $(\mathrm{x}=0.0,0.2,0.4,0.6,0.8,1.0)$ на структурні, мессбауерівські та діелектричні властивості матеріалу, отриманого методом золь-гель авто горіння. При низьких дозах заміщення в структурі співіснують дві шпінелі однакового складу: одна просторової групи Р 4332 , так звана шпінель 3 надструктурою, в якої іони заліза і літію упорядковано розміщені вздовж кристалографічного напрямку $\langle 110\rangle$ а інша просторової групи $F d 3 m$, роз впорядкована шпінель. Присутність обох шпінелей спостерігається при низькому вмісті допійованого елементу $(\mathrm{x}=0,2 \mathrm{i} 0,4)$. У випадку збільшення $\mathrm{Ni}^{2+}$ розвпорядкована компонента зникає $\mathrm{i}$ залишається тільки упорядкована фаза. Розміри частинок синтезованого продукту складають 22 - 45 нм. Згідно запропонованого катіонного розподілу іони нікелю локалізуються у тетрапідгратці а іони літію - у окта. Іони заліза перерозподіляються по обох підгратках співвідношенні приблизно 1:2. Мессбауерівська спектроскопія на проходження систем $\mathrm{Li} 0.5-\mathrm{x} / 2 \mathrm{Ni}_{\mathrm{x}} \mathrm{Fe} 2.5-\mathrm{x} / 2 \mathrm{O}_{4}$ при кімнатній температурі показала наявність трьох магнітовпорядкованих компонент і парамагнітного дублету. Показано, що провідні і діелектричні властивості синтезованих порошків носять характерну для феритових матеріалів частотну залежність, поведінка якої пояснюється на основі стрибкового механізму провідності і міжзеренної поляризації. Дані характеристики $€$ чутливими до вмісту нікелю, особливостей катіонного розподілу і мікроструктури

Ключові слова: наночастинки, золь-гель автоспалювання, літієві ферити, діелектричні властивості, магнітні властивості. 